\title{
e-Interview
}

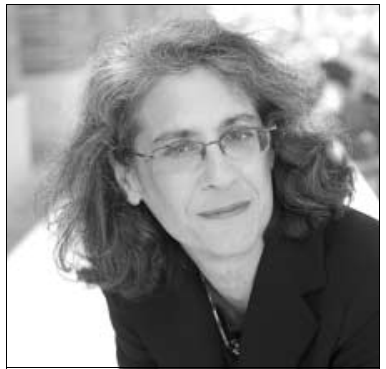

\section{Elyn R. Saks}

Elyn R. Saks is Orrin B. Evans Professor of Law, Psychology, and Psychiatry and the Behavioral Sciences at the University of Southern California, Gould School of Law. She trained at Vanderbilt and Oxford Universities, Yale Law School and the New Center for Psychoanalysis. She has written a memoir called The Centre Cannot Hold: A Memoir of My Schizophrenia. She is most interested in research.

\section{If not in your current position, what would you do?}

My dream career would be to be a good and successful novelist. Something perhaps more in my reach would be to be a psychiatrist or psychologist, specialising in psychoanalytic therapy.

\section{What has been the greatest impact} of your profession on you personally? Being a productive researcher and scholar gives me great personal satisfaction. Also, it is one of the strongest weapons in my arsenal for keeping my psychosis at bay when I am thinking, much of the crazy stuff recedes to the sidelines.

\section{Do you feel stigmatised by your profession?}

Schizophrenia is highly stigmatised, but the reception of my book discussing my schizophrenia has been almost uniformly positive - supportive, kind, expressive of gratitude, etc. I include mental health and law professionals in this group.

What are your interests outside of work? I like movies and the theatre, and I also like to eat good food. Fortunately, Los Angeles has an abundance of all of these.
Who was your most influential trainer, and why?

I can think of a number of people. Joe Goldstein, of the Yale Law School, was a rigorous, careful and interesting thinker. Steve Wizner, a clinical professor at Yale, helped me develop my skills to help others legally with mental illness. My colleague, Michael Shapiro, helped me early in my career with developing my scholarly aptitude and agenda.

What job gave you the most useful training experience?

My current job at University of Southern California Law School has given me the most useful training in being a productive scholar. Also, later in my career my research took an empirical turn, and Dilip Jeste at University of California, San Diego mentored me in that change.

\section{Which publication has influenced you} most?

I have really valued H. L. A. Hart's book, Punishment and Responsibility, and Michael Moore's book, Law and Psychiatry: Rethinking the Relationship.

\section{What part of your work gives you the} most satisfaction?

Research and writing. First drafts are my favourite part

\section{What do you least enjoy?}

I don't enjoy classroom teaching. Too many people looking at me and waiting for something to happen.

What is the most promising opportunity facing the profession?

The Recovery Movement has led people to consider quality of life and not just reduction and remission of symptoms; and has led people to allow 'consumers' themselves to define what that means for them. Further utilising consumers, and their viewpoint, could lead research in interesting and important directions. Consumers are an important and largely untapped resource.
What is the greatest threat?

Over-reliance on the use of force to get people treated.

What single change would substantially improve quality of care?

Finding out ways to get people to want treatment instead of using force.

What is the most important advice you could offer to a new trainee?

Find an area or issue you are passionate about and throw yourself into it. Also, be open to learning from your patients - they can help in both the treatment and the research contexts.

What are the main ethical problems that psychiatrists will face in the future?

If the science outpaces our humane treatment of patients - if we learn how to help them but not how to listen to and respect them, this might lead to more use of force, and that would be problematic. There are also interesting ethical issues surrounding psychiatric research. Also, genetics research may lead to findings that could stigmatise or penalise people -

figuring out a way to avoid this will be most important.

What single change to mental health legislation would you like to see?

I would like a law that leads to drastic reductions in the use of four- or six-point restraints. The UK is very good on this, the USA a lot spottier. The time for change is now.

What single area of psychiatric practice is most in need of development? Again, we need to develop techniques to get people to want treatment.

What single area of psychiatric research should be given priority?

Though hard to study, I would like to see research into psychosocial treatments, even including psychoanalytic psychotherapy, as a part of the treatment for people with psychoses. If the patient is on a good antipsychotic and treated by a good therapist, is the combined treatment effective, and in what ways?

Dominic Fannon

doi: 10.1192/pb.bp.111.035550 